\title{
Attitudes towards Using Standard Arabic among Academic Staff at Balqa Applied University/Center in Jordan: A Sociolinguistic Study
}

\author{
Rabab A. Mizher ${ }^{1} \&$ Fawwaz Al-Abed Al-Haq ${ }^{2}$ \\ ${ }^{1}$ Salt College for Human Sciences, Balqa Applied University, Salt, Jordan \\ ${ }^{2}$ Faculty of Arts, Yarmouk University, Irbid, Jordan \\ Correspondence: Rabab A. Mizher, Salt College for Human Sciences, Balqa Applied University, Salt, Amman \\ 11937, Jordan. E-mail: rabab_mizher@bau.edu.jo
}

Received: November 27, 2013 Accepted: December 24, 2013 Online Published: January 23, 2014

doi:10.5539/ijel.v4n1p53

URL: http://dx.doi.org/10.5539/ijel.v4n1p53

\begin{abstract}
The course of this study aims to investigate the attitudes of Balqa Applied University academic staff towards using Standard Arabic as the language of instruction at the university and in their social gatherings. The academic staff attitudes reflect the status of Arabicization course of action as a language planning activity among institutions of higher education in Jordan in light of competing challenges between pro-Arabicization group and anti-Arabicization group. The participants of the academic staff cover four faculties, Engineering, Agriculture, Human Sciences, and Planning. The findings of the study confirmed the passion for Standard Arabic as a highly elevated language. The respondents encourage the use of Standard Arabic in academic context in general and in conferences held at local and national levels. Standard Arabic is also preferable among other Arabs' academic interaction. However, the respondents are rather unenthusiastic pertaining to using Standard Arabic in social interaction. In light of the findings of the study, it is recommended that the administration of higher academic institutions in Jordan assume an effective role in promoting Arabicization.
\end{abstract}

Keywords: Arabicization, language planning, higher education in Jordan, pro-Arabicization, anti-Arabicization

\section{Introduction}

In light of augmenting alternatives of communication varieties in the eve of $21^{\text {st }}$ Century, language planning ought effectively and steadily to cope up with the demands of the new era with regard to various domains including religious, political, scientific, social, cultural and academic ones. One may hardly deny the influence of what is called the "Arab Spring" on the emotional empowerment of the Arab Nation which is represented by fortifying the Arab identity, thus hopefully leading to a solid foundation of a balanced resistance front to encounter the dynamic control of globalization on the various aspects of life in the Middle East and North Africa (MENA).

The political and social changes on the ground impose challenges on sociolinguists. They ought to utilize Arabicization from language planning perspective to cope up with the changing face of the region. Upon considering the descriptive nature of sociolinguistics, Language planning needs not to be restricted to planners of authoritative agencies nor the target group and the ideal form of language planning need to be restricted as well (Al-Abed Al-Haq, 1992).

The terms Arabization and Arabicization are used interchangeably in most sociolinguistic literature. Nevertheless, Al-Abed Al-Haq (1992, p. 55) stated that Arabization indicates a reference to the people and culture of the Arabs, while Arabicization is derived morphologically from Arabic language so it is more appropriate for Arabicization Planning. Although this distinction is adopted by the researchers, they notice that the contemporary literature uses Arabization mostly to refer to both.

\subsection{Islam, Politics and Arabicization}

While the Arab peoples are gradually gaining confidence in themselves as agents of change, the other will not remain passive. The active role of the west against what is called "Islam phobia" on one hand and that of some Non-Arab Muslims on the other hand impose major challenges on Arabization proponents although both have totally paradoxical intentions. To a certain extent, no one denies the hostility against Islam and the Arabs following September 11, 2001 attacks; however, the Arabicization process in the west has flourished due to 
political defensive reasons. One of these reasons is illustrated in Israel.

In an article published in the Israeli newspaper Haaretz entitled Israel Shameful Attack on Arabic must be stopped on the $15^{\text {th }}$ of November 2011, Moshe Arnes attacks some members of Knesset proposal to strip the Arab language from its current official status as the Arabic is the best interest of both Jewish majority and Arab minority. He elaborates that Jewish children should learn Arabic not only to be able to communicate with Arabs, but also "as a sign of Israel's respect and consideration for its Arab minority".

By contrast, some non-Arab Muslims keep emphasizing the notion that the universality of Islam necessitates de-Arabization. Zubaidi (as cited in Sabet, 2010) challenges the claim "made by modern Islamic movements that 'the people' are the bearers and agents of the Islamic heritage", thus Islamization and Arabization are not correlated. Moreover, Ghoshal (2008, p. 4) perceives Arabization in Asia as a force that

poses a threat to all Muslims who believe in Islam's divine character and universalism, and can be combated only by them. It is not a crisis between civilizations..., but a crisis within civilization and can be fought from within. Arabization's major appeal emanates from Islam's millenary expectations and the unfounded utopia of a just and prosperous society under Islamic rule. This is also fed by the silence of the moderates in the face of the more vocal minority trying to hijack Islam for their perverted gain.

The above illustrative examples add other subgroups to Al-Abed Al-Haq (1992) classification of the trends of Arabicization as language planning activity. Al-Abed Al-Haq (1992, p. 57) considers three trends: Pro-Arabicization, Anti-Arabicization and Undecided Arabicization. Pro-Arabicization is adopted for either religious or nationalistic purposes, whereas anti-Arabicization is adopted for either instrumental or westernization purposes. There might be a third defensive subgroup for pro-Arabicization; and Islam universality subgroup for anti-Arabicization.

\section{Purpose of the Study}

Upon emphasizing the descriptive nature of sociolinguistics, this paper attempts to measure the attitudes toward using Standard Arabic in academic formal gatherings such as lectures, conferences, cultural circles in addition to social informal gathering of academic staff. The paper is in line with the notion that addresses Arabicization from language planning perspective (Al-Abed Al-Haq, 1992).

\section{Question of the Study}

This paper attempts to answer the following question: To what extent do academic staff members at Balqa Applied University-center use Standard Arabic in their academic and social gatherings?

\section{Review of Related Literature}

Al-Asal and Smadi (2012) observe the use of Arabic in lectures when facing scientific terms among faculty members of two Arab universities in Jordan and Syria. The findings of the study revealed that the transliterated scientific terms are higher in frequency in the Jordanian University while the use of Arabic equivalents is higher in frequency in the Syrian University. The study also confirmed that the use of "English is as a medium of instruction continues to dominate the sciences in JUST" [Jordan University of Science and Technology] (p. 32). This could be attributed to the fact that English is the language of science, research, technology, etc., because "[m]ost of the books, periodicals, papers, and electronic databases essential for the intensive and extensive study of an academic subject are written in English" (p. 32).

Chakrani (2011, p. 168) states that "Standard Arabic (SA), the H local code, enjoys considerable overt prestige as the official language in Morocco and has served as a language of public education and learning in the pre-colonial, colonial, and post-colonial eras." However, it should be placed as a global language so as to maintain its powerful status, otherwise French will continue to be a dominant language in higher education, business, and foreign affairs as Moroccan students attitudes perceives French as language of post-modernity not Standard Arabic.

Al-Abed Al-Haq and Massaeid (2009) highlight the pivot role of adopting a language planning policy so as Arabicization gains momentum in the Arab World. The researchers studied the attitudes of four Jordanian university students towards language planning in Jordan. The findings of the study revealed that language planning in Jordan is associated with the religious ideology of Islam and that Arabic occupies a considerable level in daily communication, media and education. On the other hand, the study also proved that English is regarded as a threat to Arabic in various domains in Jordan. Jordanian university students regard English as the language of future opportunities in education, business and trade.

Sharkey (2008) admits that Sudan entails the gradual spread of both Arab identity and the Arabic language as 
part of post-colonial policy that has been adopted after independence. However, such a top-down policy is not totally realized on the ground due to various political reasons. He negatively associates Arabization as post-colonial policy with conflicts in Nuba Mountains, Southern Sudan and Darfur.

Nevertheless, the findings of Murad (2007) on attitudes of Iraqi students toward using Standard Arabic (SA) and Iraqi Arabic (IA) showed that "the higher the speaker's educational level, the more they are inclined to favor SA over IA. Conversely, the lower the speaker's educational level... the more favorable their disposition would be for IA." (p. 113) In Algeria, Arabic remains a well subscribed language within secondary education (Messaoudi, 2006, p. 317).

Al-Abed Al-Haq (1998) in Jordan measures the attitudes of Academic staff at Yarmouk University toward Standard Arabic and the promotion of the Arabicization. The findings reflect "a widely felt awareness of and enthusiasm for Standard Arabic and Arabicization" (p. 30). The respondents realize that SA is "the means of wide communication or lingua franca among Arabs... [as] oral communication across the Arab countries would be difficult without Standard Arabic" (p. 30). The respondents of the study also encourage the idea that the government should pass a resolution for which SA is used as a medium of instruction at Jordanian university through which Arabicization is adopted as an academic duty.

The course of this paper is in compliance with Al-Abed Al-Haq (1998) study as for the best knowledge of the researchers; there are almost no studies that measure the attitudes of the higher education academic staff toward Standard Arabic and Arabicization in the Arab World in nearly the last ten years. Consequently, the researchers examine the attitudes of the academic staff at Balqa Applied University-Center so as to explore these attitudes in light of the contemporary changing atmosphere in the Arab World.

\section{Methods and Procedures}

\subsection{Participants of the Study}

The participants of the study are 25 members of academic staff at Balqa Applied University-Center. These members instruct at the faculties of Engineering 24\%, Agriculture 24\%, Human Sciences 36\% and Planning 16\%. Their academic ranks are associate professors $16 \%$, assistant professors $24 \%$, instructors $20 \%$, assistant instructors $8 \%$ and full-time lecturers $32 \%$. Their ages are below $3024 \%$, below $4032 \%$, below $5024 \%$, below $6020 \%$. Most of the professors at the faculties of Engineering and Agriculture got their PhDs and MA from America, German, Australian and Russian Universities with $24 \%$. Whereas most of the academic staff at the faculties of Human Sciences and Planning got their PhDs and MA from Jordanian Universities with $64 \%$ and Arab Universities in Egypt, Iraq and Tunisia with 12\%.

\subsection{Instrument of the Study}

The instrument of the study is a questionnaire adopted from Al-Abed Al-Haq (1998) and slightly modified to suit the contemporary social and political atmosphere in Jordan. Accordingly it is valid and reliable.

\subsection{Limitation of the Study}

The generalizability of the findings of the study is limited to the participants and items of the questionnaire. However, the participants' features may reflect a considerable range of academic staff at Jordanian Universities.

\section{Findings and Discussion}

The major finding of the study reflects passion for Standard Arabic as a highly elevated language with grand mean of the attitudes of 3.74 at Likert Scale. Standard Deviation of total attitudes is .48 which makes the variance .23 , thus reflects homogeneity of the study respondents. The questionnaire is analyzed considering four major perspectives; the Standard Arabic Status, Standard Arabic and Academia, Standard Arabic and Cultural Interaction, Standard Arabic and Social Interaction, and Standard Arabic and Politics. 


\subsection{Standard Arabic Status}

Table 1. Percentages, means and standard deviations of standard Arabic status items

\begin{tabular}{|c|c|c|c|c|c|c|c|c|}
\hline No. & Item & $\begin{array}{r}\text { Strongly } \\
\text { Agree }\end{array}$ & Agree & $\begin{array}{l}\text { Not } \\
\text { Sure }\end{array}$ & $\begin{array}{r}\text { Dis- } \\
\text { agree }\end{array}$ & $\begin{array}{l}\text { Strongly } \\
\text { Disagree }\end{array}$ & Mean & SD \\
\hline 1 & $\begin{array}{l}\text { I believe that Standard Arabic (SA) is } \\
\text { generally superior to the colloquial }\end{array}$ & 68.0 & 28.0 & 04.0 & 00.0 & 00.0 & 4.64 & 1.26 \\
\hline 2 & I believe that SA is a beautiful language & 92.0 & 08.0 & 00.0 & 00.0 & 00.0 & 4.92 & 0.28 \\
\hline 3 & $\begin{array}{l}\text { I believe we must promote the usage of } \\
\text { SA at all levels }\end{array}$ & 62.5 & 29.2 & 04.2 & 04.2 & 00.0 & 4.50 & 0.78 \\
\hline 4 & $\begin{array}{l}\text { I wish I had better level of performance in } \\
\text { SA }\end{array}$ & 56.0 & 32.0 & 08.0 & 04.0 & 00.0 & 4.40 & 0.82 \\
\hline 5 & $\begin{array}{l}\text { I believe that we must be loyal and } \\
\text { enthusiastic toward Arabicization }\end{array}$ & 52.0 & 44.0 & 04.0 & 00.0 & 00.0 & 4.48 & 0.59 \\
\hline 6 & $\begin{array}{l}\text { I believe that planning for Arabicization } \\
\text { is a necessity for make it successful }\end{array}$ & 48.0 & 52.0 & 00.0 & 00.0 & 00.0 & 4.48 & 0.51 \\
\hline 7 & $\begin{array}{l}\text { I believe that planning for Arabicization } \\
\text { is as important as other types of planning } \\
\text { (social, economic, etc.) }\end{array}$ & 40.0 & 56.0 & 04.0 & 00.0 & 00.0 & 4.36 & 0.57 \\
\hline 8 & $\begin{array}{l}\text { I believe that Arabicization is a national } \\
\text { and academic duty }\end{array}$ & 44.0 & 56.0 & 00.0 & 00.0 & 00.0 & 4.44 & 0.51 \\
\hline 9 & $\begin{array}{l}\text { I believe that people who are involved in } \\
\text { Arabicization must be rewarded }\end{array}$ & 37.5 & 54.2 & 08.3 & 00.0 & 00.0 & 4.29 & 0.62 \\
\hline
\end{tabular}

Table 1 refers to significant total agreement among respondents on the highly elevated status of the Standard Arabic. The Disagree and Strongly Disagree columns are almost null; while the mean is fluctuating between 4.29 and 4.92 which is considerably the highest among all questionnaire categories. The SD also reflects high agreement among respondents. The $92 \%$ of Statement number 2 reveals the religious aspect of SA as it is the language of The Glorious Quran and the pride that the Arabs have for their identity and language.

\subsection{Standard Arabic and Academia}

Table 2. Percentages, means and standard deviations of SA and academia items

\begin{tabular}{|c|c|c|c|c|c|c|c|c|}
\hline No. & Item & $\begin{array}{r}\text { Strongly } \\
\text { Agree }\end{array}$ & Agree & Not Sure & $\begin{aligned} \text { Dis- } \\
\text { agree }\end{aligned}$ & $\begin{array}{l}\text { Strongly } \\
\text { Disagree }\end{array}$ & Mean & SD \\
\hline 1 & $\begin{array}{l}\text { I feel that I am not educated if I talk in } \\
\text { Jordanian colloquial in front of friends } \\
\text { from other Arab countries }\end{array}$ & 04.0 & 28.0 & 12.0 & 32.0 & 24.0 & 2.56 & 1.26 \\
\hline 2 & $\begin{array}{l}\text { I prefer to talk in SA with my Arab } \\
\text { friends }\end{array}$ & 04.0 & 08.0 & 28.0 & 44.0 & 16.0 & 2.40 & 1.00 \\
\hline 3 & $\begin{array}{l}\text { I believe that SA must be used at the } \\
\text { university level to achieve maximum } \\
\text { mutual understanding }\end{array}$ & 45.8 & 41.7 & 4.2 & 08.3 & 00.0 & 4.25 & 0.90 \\
\hline 4 & $\begin{array}{l}\text { I believe that the level of competency in } \\
\text { SA must be one of the criterion for the } \\
\text { appointment at a university }\end{array}$ & 25.0 & 45.8 & 04.2 & 25.0 & 00.0 & 3.71 & 1.12 \\
\hline 5 & $\begin{array}{l}\text { I believe that incompetence in SA will } \\
\text { lead to difficulties in academic } \\
\text { performance }\end{array}$ & 37.5 & 37.5 & 25.0 & 00.0 & 00.0 & 4.13 & 0.80 \\
\hline
\end{tabular}


6 I believe that professors must encourage students to use SA

7 I believe we must use SA in conferences held at local and national level

I believe that there must be a political

8 decree that requires the Jordanian universities to use SA

9 I believe the professors must not be appointed at the universities unless they translate their dissertations written in a foreign language into Arabic

10 I believe that writing in SA of publishing an article in SA should be one of the requirements of academic promotion

11 I believe that instructors who are competent in SA must be given priority over those who are not, for scholarships and training programs

\begin{tabular}{|c|c|c|c|c|c|c|}
\hline 40.0 & 56.0 & 04.0 & 00.0 & 00.0 & 4.36 & 0.57 \\
\hline 64.0 & 36.0 & 00.0 & 00.0 & 00.0 & 4.64 & 0.49 \\
\hline 36.0 & 32.0 & 04.0 & 28.0 & 00.0 & 3.75 & 1.23 \\
\hline 28.0 & 16.0 & 24.0 & 24.0 & 08.0 & 3.32 & 1.35 \\
\hline 32.0 & 28.0 & 24.0 & 16.0 & 00.0 & 3.76 & 1.09 \\
\hline 24.0 & 44.0 & 12.0 & 16.0 & 04.0 & 3.68 & 1.14 \\
\hline
\end{tabular}

Table 2 shows that the responses to SA and Academia statements are somehow varied. Yet, the grand mean for this particular category is 3.68 at Likert Scale which is again a high one. What is significant is their responses to the first two statements, where around $56 \%$ to $60 \%$ disagree with the idea that speaking in colloquial Jordanian or listening to other colloquial Arabic does not underestimate their characters as educated people.

There is also a noticeable variance in agreement upon the idea that requires the use of Standard Arabic at an official level. Almost 44\% agree with the idea that dissertations written in other languages than Arabic should be translated into Arabic when the instructor is appointed at the university, 32\% disagree with that statement and $24 \%$ are neutral. Such a tendency reflects the active materialistic role that these instructors are ought to play if they agree with the statement. Yet, if the university has asked translators to do the job, I believe there will be somehow agreement on this item.

Remarkable percentages are observed in items 7, 6 and 3 with $100 \%, 96 \%$ and $88 \%$ respectively. The three statements reflect the image that university instructors try to establish by utilizing the prestigious nature Standard Arabic during official academic meetings at lectures and conferences.

\subsection{Standard Arabic and Cultural Interaction}

Table 3. Percentages, means and standard deviations of SA and cultural interaction items

\begin{tabular}{|c|c|c|c|c|c|c|c|c|}
\hline No. & Item & $\begin{array}{r}\text { Strongly } \\
\text { Agree }\end{array}$ & Agree & $\begin{array}{l}\text { Not } \\
\text { Sure }\end{array}$ & $\begin{array}{r}\text { Dis- } \\
\text { agree }\end{array}$ & $\begin{array}{l}\text { Strongly } \\
\text { Disagree }\end{array}$ & Mean & SD \\
\hline 1 & $\begin{array}{l}\text { I believe that students do not like seeing their } \\
\text { professors talking in colloquial language while } \\
\text { giving a lecture }\end{array}$ & 12.5 & 12.5 & 37.5 & 29.2 & 08.3 & 2.29 & 1.14 \\
\hline 2 & $\begin{array}{l}\text { I feel comfortable when talking to students in } \\
\text { colloquial language while giving a lecture }\end{array}$ & 12.0 & 16.0 & 12.0 & 28.0 & 12.0 & 2.68 & 1.25 \\
\hline 3 & $\begin{array}{l}\text { I feel comfortable when talking to students in } \\
\text { SA while giving a lecture }\end{array}$ & 20.0 & 36.0 & 24.0 & 12.0 & 08.0 & 3.48 & 1.19 \\
\hline 4 & $\begin{array}{l}\text { I believe that the usage of SA is distinctive } \\
\text { feature of a well-educated person }\end{array}$ & 28.0 & 44.0 & 16.0 & 12.0 & 00.0 & 3.88 & 0.97 \\
\hline 5 & $\begin{array}{l}\text { I believe that the importance of using Arabic is } \\
\text { clear when meeting Arabs from different Arab } \\
\text { countries }\end{array}$ & 41.7 & 41.7 & 08.3 & 08.3 & 00.0 & 4.17 & 0.92 \\
\hline
\end{tabular}


6. I believe it is necessary to talk in SA when I meet Arabs from different Arab countries I believe if I happen to be in one of the Arab countries, I will talk in SA

8 presence of other Arabs

$\begin{array}{rrrrrrr}44.0 & 36.0 & 16.0 & 04.0 & 00.0 & 4.20 & 0.87 \\ 20.0 & 40.0 & 28.0 & 04.0 & 08.0 & 3.60 & 1.12 \\ 24.0 & 48.0 & 12.0 & 16.0 & 00.0 & 3.80 & 1.00\end{array}$

Table 3 reveals respondents variance pertaining to Standard Arabic and cultural interaction. However responses are homogenous. The highest agreement is observed in item 5 which is in line with the tendency of the whole questionnaire. The highest disagreement is on item 2 with $40 \%$, which is again in compliance with dominating trend that promotes the SA in official academic meetings rather than colloquial Jordanian Arabic.

\subsection{Standard Arabic and Politics}

Table 4. Percentages, means and standard deviations of SA and politics items

\begin{tabular}{|c|c|c|c|c|c|c|c|c|}
\hline No. & Item & $\begin{array}{r}\text { Strongly } \\
\text { Agree }\end{array}$ & Agree & $\begin{array}{l}\text { Not } \\
\text { Sure }\end{array}$ & $\begin{array}{r}\text { Dis- } \\
\text { agree }\end{array}$ & $\begin{array}{l}\text { Strongly } \\
\text { Disagree }\end{array}$ & Mean & SD \\
\hline 1 & $\begin{array}{l}\text { I believe that there are recent trends toward } \\
\text { promoting Arabic under the umbrella of } \\
\text { Democratization }\end{array}$ & 04.2 & 37.5 & 33.3 & 25.0 & 00.0 & 3.21 & 0.88 \\
\hline 2 & $\begin{array}{l}\text { I believe that democratization in Jordan helps } \\
\text { to promote SA through political parties, } \\
\text { pamphlets and publications }\end{array}$ & 09.1 & 27.3 & 36.4 & 27.3 & 00.0 & 3.18 & 0.96 \\
\hline
\end{tabular}

Table 4 reveals a sort of equilibrium among respondents to SA and politics with almost $70 \%$ of Not Sure column, an idea that could reflect to a certain extent the cautiousness the respondents assume towards political issues.

\subsection{Standard Arabic and Social Interaction}

Table 5. Percentages, means and standard deviations of SA and social interaction items

\begin{tabular}{|c|c|c|c|c|c|c|c|c|}
\hline No. & Item & $\begin{array}{r}\text { Strongly } \\
\text { Agree }\end{array}$ & Agree & $\begin{array}{r}\text { Not } \\
\text { Sure }\end{array}$ & $\begin{array}{r}\text { Dis } \\
\text { agree }\end{array}$ & $\begin{array}{l}\text { Strongly } \\
\text { Disagree }\end{array}$ & Mean & SD \\
\hline 1 & $\begin{array}{l}\text { I feel comfortable when I use colloquial } \\
\text { while shopping }\end{array}$ & 00.0 & 08.0 & 00.0 & 68.0 & 24.0 & 1.92 & 0.76 \\
\hline 2 & $\begin{array}{l}\text { I feel uneasy when I use SA within my } \\
\text { local community }\end{array}$ & 04.0 & 20.0 & 16.0 & 44.0 & 16.0 & 2.52 & 1.12 \\
\hline 3 & $\begin{array}{l}\text { If I use SA at home, I will be approved of } \\
\text { by my family }\end{array}$ & 12.0 & 28.0 & 20.0 & 28.0 & 12.0 & 3.00 & 1.26 \\
\hline 4 & $\begin{array}{l}\text { If I use SA in talking with my relatives, I } \\
\text { will be approved of by them }\end{array}$ & 00.0 & 25.0 & 33.3 & 29.2 & 12.5 & 2.71 & 1.00 \\
\hline 5 & I hope that my children use SA & 56.0 & 24.0 & 12.0 & 08.0 & 00.0 & 4.28 & 0.98 \\
\hline
\end{tabular}

Table 5 reflects the social aspect of academic staff. It is obvious that they agree to a certain extent the unenthusiastic tendency toward using Standard Arabic in social gatherings. The lowest mean in all questionnaire items is observed in item 1 which is related to using Standard Arabic while shopping as shopping is considered localized social activity with somehow not very educated people, consequently, communication breaks down. Otherwise there is a sort of negative agreement among respondents toward using Standard Arabic during social interaction.

\section{Conclusion}

It could be concluded that the academic staff, generally, is enthusiastic towards using Standard Arabic with 
regard to its status, academia and cultural interaction. Moderate attitudes are observed towards Standard Arabic and cultural interaction while unenthusiastic attitudes are viewed towards Standard Arabic and social interaction. Thus, it could be concluded that academic staff belong to a certain extent to pro-Arabicization group but they lack authorized policy at the administrative level that adopt a well-organized strategy so as to promote Arabicization as a language planning activity at the higher education level.

\section{References}

Al-Abed Al-Haq, F. (1992). Toward a Theoretical Framework for Planning Arabicization. In A. Shunnaq, C. Dollerup, \& M. Sarraireh (Eds.), Issues in Translation. Irbid: Irbid National University and JTA.

Al-Abed Al-Haq, F. (1998). Language Attitudes and the Promotion of Standard Arabic and Arabicization. In Al-Arabiyya.

Al-Abed Al-Haq, F., \& Al-Massaeid, A. L. (2009). Islam and Language Planning in the Arab World: A Case Study in Jordan. Iranian Journal of Language Studies (IJLS), 3(3), 267-302.

Al-Asal, M. S., \& Smadi, O. M. (2012). Arabicization and Arabic Expanding Techniques Used in Science Lectures in Two Arab Universities. Asian Perspectives in the Arts and Humanities, 2(1), 15-38.

Arnes, M. (2011, November 15). Israel Shameful Attack on Arabic must be stopped. Haaretz. Retrieved November 16 , 2011 ,

from http://www.haaretz.com/print-edition/opinion/israel-s-shameful-attack-on-arabic-must-be-stopped-1.395617

Chakrani, B. (2011). Covert Language Attitudes: A New Outlook on the Sociolinguistic Space of Morocco. In E. G. Bokamba et al. (Eds.), Selected Proceedings of the 40th Annual Conference on African Linguistics (pp. 168-177). Somerville, MA: Cascadilla Proceedings Project. Retrieved December 13, 2011, from http://www.lingref.com/cpp/acal/40/paper2573.pdf

Ghoshal, B. (2008). Arabization: Changing Face of Islam in Asia. New Delhi: Institute of Peace and Conflict Studies. http://dx.doi.org/10.1177/097492841006600105

Messoudi, A. (2006). The Teaching of Arabic in French Algeria and Contemporary France. Oxford: Oxford University Press. http://dx.doi.org/10.1093/fh/crl020

Murad, M. K. (2007). Language Attitudes of Iraqi Native Speakers of Arabic: A Sociolinguistic Investigation. (Unpublished master's thesis). Retrieved December 7, 2011, from http://search.proquest.com.ezproxy.bau.edu.jo/pqdttt/docview/304859215/previewPDF/1337FB7AF1C24E 47F60/37? accountid $=31746$

Sabet, A. (2010). Book Review: Islam, The People and The State: Political Ideas and Movements in the Middle East by Sami Zubaidi (2009). Retrieved December 15, 2011, from http://jis.oxfordjournals.org/

Sharkey, H. (2008). Arab Identity and Ideology in Sudan: The Politics of Language Ethnicity and Race in African Affairs. Oxford: Oxford University Press. http://dx.doi.org/10.1093/afraf/adm068

\section{Copyrights}

Copyright for this article is retained by the author(s), with first publication rights granted to the journal.

This is an open-access article distributed under the terms and conditions of the Creative Commons Attribution license (http://creativecommons.org/licenses/by/3.0/). 